\title{
Inhibitory Effects of Gallic Acid Isolated from Caesalpinia mimosoides Lamk on Cholangiocarcinoma Cell Lines and Foodborne Pathogenic Bacteria
}

\author{
Narintorn Rattanata ${ }^{1}$, Sompong Klaynongsruang ${ }^{1}$, Sakda Daduang ${ }^{2}$, Ratree \\ Tavichakorntrakool ${ }^{3}$, Temduang Limpaiboon ${ }^{3,4}$, Ratsami Lekphrom ${ }^{5}$, Patcharee \\ Boonsiri $^{6}$, Jureerut Daduang ${ }^{3,4 *}$
}

\begin{abstract}
Gallic acid was isolated from Caesalpinia mimosoides Lamk and the structure s identified based on spectroscopic analysis and comparison with authentic compound. In this study we compared the ability of natural gallic acid (nGA) and commercial gallic acid (cGA) to inhibit the proliferation of cholangiocarcinoma cell lines (M213, M214) and foodborne pathogenic bacteria (Salmonella spp. and Plesiomonas shigelloides). Both nGA and cGA had the same inhibitory effects on cell proliferation by inducing apoptosis of cholangiocarcinoma cell lines. In addition, nGA inhibited growth of foodborne pathogenic bacteria in the same manner as cGA. Our results suggest that nGA from Caesalpinia mimosoides Lamk is a potential anticancer and antibacterial compound. However, in vivo studies are needed to elucidate the specific mechanisms involved.
\end{abstract}

Keywords: Anticancer activity - cholangiocarcinoma - antibacterial activity - foodborne pathogen

Asian Pac J Cancer Prev, 17 (3), 1341-1345

\section{Introduction}

Cancer and diarrheal diseases are major causes of mortality in developing countries (WHO, 2012). There are limitations to the standard treatments for cancer, especially when treating patients in the advanced stages of the disease (Khan et al., 2002; Thongprasert, 2005). Bacterial foodborne illnesses are also a common problem worldwide, including those caused by Salmonella spp. and Plesiomonas shigelloides. Many antibiotics have been extensively used, leading to increases in drug-resistant bacteria (Collignon 2009; Abatcha et al., 2014). Therefore, alternative therapeutic agents with anticancer and antibacterial activities are needed. Bioactive compounds from plant phytochemicals could be a potential source for effective drugs as well as food supplements and nutraceuticals. Caesalpinia mimosoides Lamk ( $C$. mimosoides Lamk) is an Asian vegetable; the young shoots and leaves are consumed, indicating that plant compounds could be safely used as therapeutics. Extensive experimental works over the past decade have identified beneficial effects of $C$. mimosoides Lamk related to its antimicrobial activities (Chanwitheesuk et al., 2007; Daduang et al., 2011), antioxidant activities
(Chanwitheesuk et al., 2005), anti-inflammatory activities (Yodsaoue et al., 2010), and neuroprotective effects (Tangsaengvit et al., 2013). Moreover, it has been reported that $C$. mimosoides Lamk possesses anticancer effects via the apoptosis pathway (Palasap et al., 2014). This study examines the beneficial effects of phytochemicals from $C$. mimosoides Lamk, including anticancer activity towards cholangiocarcinoma cell lines and antimicrobial effects on the foodborne pathogenic bacteria Salmonella spp. and Plesiomonas shigelloides.

\section{Materials and Methods}

\section{Chemicals and reagents}

Hexane, ethyl acetate, and methanol were purchased from S.C. Science Co., Ltd. (Thailand). Silica gel 60 and thin layer silica gel 60 F254 were purchased from Merck (Germany). Dulbecco's modified Eagle's medium-high glucose (DMEM-HG), fetal bovine serum, penicillinstreptomycin, and trypsin-EDTA were obtained from Gibco BRL (Grand Island, NY). Catechin, quercetin, ferulic acid, rutin, caffeine, gallic acid and neutral red were obtained from Sigma-Aldrich Co. LLC. The other chemicals used were all reagent grade. 


\section{Plant material and extraction}

Shoot and leaves of $C$. mimosoides Lamk were collected from the Udon Thani province in January 2014. The taxonomic identity was confirmed by Prof. Dr. Arunrat Chaveerach, Department of Biology, Faculty of Science, Khon Kaen University. Samples were washed with tap water and air-dried at $50^{\circ} \mathrm{C}$. C. mimosoides Lamk powder $(0.95 \mathrm{~kg})$ was obtained by crushing the plants with an electric blender. Then, it was extracted by incubation in 4 liters of ethyl acetate (EtOAc) at room temperature for $24 \mathrm{hr}$. This process was repeated for $24 \mathrm{hr}$, and the solvents were combined. Removal of the solvent from the extract was performed under reduced pressure by a rotary evaporator (BUCHI, Model R240). Finally, 29.61 $\mathrm{g}$ of crude EtOAc extract was stored in desiccators for further purification.

\section{Isolation of crude ethyl acetate extract}

The crude EtOAc extract was separated by silica gel column chromatography. Silica gel (silica gel F254 size $0.063 \mathrm{~mm}$ ) was packed into a glass column $(8 \mathrm{~cm} \times 60$ $\mathrm{cm}$ ) and $29.61 \mathrm{~g}$ of crude EtOAc extract was applied to the column. The phytochemical compounds were separated by gradually increasing the polarity of the eluting solvents: hexane, hexane:EtOAc, EtOAc, EtOAc:methanol (MeOH) and $\mathrm{MeOH}$, respectively. Two column volumes of each eluate were collected and characterized by thin layer chromatography (TLC). TLC was carried out by spotting the sample on a silica gel 60 F254 precoated alumina sheet (Merck, Cat. No. MC1057190001) and using the same mobile phase system as described above. Spots were visualized under ultraviolet (UV) light at 254 and 365 $\mathrm{nm}$. The chemical reactivity of these fractions was also tested by oxidizing with p-anisaldehyde, and 5 fractions, named E1-E5, showed positive results. The $30.10 \mathrm{mg}$ of the selected fraction E4 was re-separated on a silica gel column and eluted with the same eluting system described above. The subfraction number E4.4.5 was obtained and recrystallized with EtOAc for characterization.

\section{Characterization by high performance liquid chromatography (HPLC)}

High performance liquid chromatography (HPLC) was used into characterize the compounds from fraction E4.4.5. Twenty microliters of the tested fraction was injected on a C18- Symmetry column, size $15 \mathrm{~cm}$ x 3.0 $\mathrm{mm}, 5 \mu \mathrm{m}$ (Waters). The compounds were separated using a gradient elution of $\mathrm{MeOH}$ and $0.5 \%$ phosphoric acid. The gradient was run with 5\%,70\% and 90\% $\mathrm{MeOH}$ from 0-17 min, 17-18 min and 18-20 min, respectively, at a flow rate of $1.5 \mathrm{ml} / \mathrm{min}$. Gallic acid, catechin, caffeine, ferulic acid, rutin, and quercetin were used as standard compounds by measuring the absorbance at $270 \mathrm{~nm}$ (Waters, UV 2479). The peaks were analyzed by the Clarity program (Waters).

A white solid obtained from fraction E4.4.5 was further characterized by ${ }^{1} \mathrm{H}$ and ${ }^{13} \mathrm{C}$ nuclear magnetic resonance spectroscopy (NMR) (Varian NMR-400 MHz Spectrometer).

\section{Cancer cell cultures}

Human cholangiocarcinoma (CCA) cell lines M213 and M214 were obtained from Prof. Banchob Sripa, Department of Pathology, Faculty of Medicine, Khon Kaen University. They were cultured in RPMI 1640 medium supplemented with $10 \%$ FBS and $1 \%$ penicillinstreptomycin (Sigma-Aldrich) at $37^{\circ} \mathrm{C}$ in a $\mathrm{CO}_{2}$ incubator (95\% relative humidity, $5 \% \mathrm{CO}_{2}$ ). Cell lines were trypsinized with $1 \mathrm{X}$ trypsin-EDTA when they reached confluence.

\section{Cell viability and $\mathrm{IC}_{50}$ determination}

A neutral red (NR) assay modified from Borenfreund and Puerner (1984) was used to test for cell viability. Briefly, cells were detached from the culture flask using $1 \mathrm{X}$ trypsin-EDTA. Then, RPMI supplemented with 10\% FBS was added. The cells were counted using a hemocytometer, and approximately 6,000 cells were seeded per well in a 96-well plate. The cells were cultured in complete RPMI 1640 medium at $37^{\circ} \mathrm{C}$ in a $\mathrm{CO}_{2}$ incubator for $24 \mathrm{hr}$. All the cell lines were treated with varying concentrations $(30,50$, $70,90,110,120150$ and $170 \mu \mathrm{M}$ ) of nGA and incubated for an additional $24 \mathrm{hr}$. NR was added to the test cells for $3 \mathrm{hr}$. Cell viability was detected at $540 \mathrm{~nm}$ using an RT2100c microplate reader (Rayto, China). In parallel, cGA was also tested to compare cell growth inhibition to nGA.

\section{Morphological changes}

The morphological changes of M213 and M214 cells treated with $\mathrm{IC}_{50}$ values of cGA for $24 \mathrm{hr}$ were observed by staining with $5 \mathrm{mg} / \mathrm{ml}$ of 4',6-diamidino-2-phenylindole (DAPI) for $10 \mathrm{~min}$ and analyzing under a fluorescence microscope.

\section{Antimicrobial activity test}

The gallic acid from $C$. mimosoides Lamk was then evaluated for its antibacterial activity. The 2 human pathogenic bacterial strains tested were Salmonella spp. (serogroup B) and Plesiomonas shigelloides. They were obtained from the Department of Clinical Microbiology at the Faculty of Associated Medical Sciences, Khon Kaen University.

The minimum inhibition of concentration (MIC) of nGA and cGA was investigated using the disc diffusion method (Bauer et al.,1966). For each species, 0.5 McFarland inoculums were swabbed onto nutrient agar plates; then, $20 \mu \mathrm{L} \mathrm{nGA}$ and cGA at concentrations of $10-140 \mathrm{mM}$ was added to the $6 \mathrm{~mm}$ diameter sterile paper discs on dried plates and placed on the test plate. After incubation at $37^{\circ} \mathrm{C}$ for $16-24 \mathrm{hr}$, the diameters of the clear zones that appeared were measured; $10 \%$ dimethylsulfoxide (DMSO) was the negative control, and $10 \mu \mathrm{g}$ ampicillin was the positive control. The lowest concentration of the tested compound that showed no visible growth was reported as the MIC. All experiments were conducted in triplicate. The percent inhibition was calculated as shown in the following formula.

$\%$ Inhibition $=\frac{(\text { zone of sample test-zone of negative control })}{(\text { zone of positive control })} \times 100$

\section{Scanning electron microscopy (SEM)}

SEM was performed following the method described in Uawonggul et al. (2007), with slight modifications. 
Briefly, bacterial strains were cultured in nutrient broth and harvested at the logarithmic phase of growth, washed twice with phosphate buffered saline ( $\mathrm{pH} 7.0)$, and re-suspended to yield a final concentration of $10^{6} \mathrm{CFU} / \mathrm{ml}$. Aliquots of the bacterial suspension $(100 \mu \mathrm{L})$ were individually incubated with the previously determined MIC of cGA at $110 \mathrm{mM}$ for Plesiomonas shigelloides and $117 \mathrm{mM}$ for Salmonella spp. at $37^{\circ} \mathrm{C}$ for 1 and $2 \mathrm{hr}$, respectively. The treated bacteria $(150 \mu \mathrm{L})$ were fixed with equal volumes of $2.5 \%$ glutaraldehyde (Sigma-Aldrich Co. LLC) in a $0.1 \mathrm{M}$ phosphate buffer, $\mathrm{pH} 7.2$, for $2 \mathrm{hr}$ and pipetted onto $0.2 \mu \mathrm{M}$ polycarbonate membrane filters (Whatman, Germany) for $5 \mathrm{~min}$. The materials were dehydrated in graded ethanol concentrations $(30,50,70$ and $90 \%)$ for 15 min each and then coated with gold palladium by a sputter coater (Polaron, SC7620, England) and examined with a scanning electron microscope (LEO Electron Microscopy Ltd., LEO1450VP, England) operated at 12 to $20 \mathrm{kV}$. For the negative control, all procedures were performed in a similar manner, except that the bacterial cells were incubated with a PBS buffer instead of cGA.

\section{Results}

Compounds from fraction E4.4.5

The phytochemical composition of E4.4.5 was first screened by HPLC. The retention times of gallic acid, catechin, caffeine, ferulic acid, rutin, and quercetin standard compounds were $4.91,9.14,10.34,12.22$, 14.51 and $17.28 \mathrm{~min}$, respectively. The retention time of E4.4.5 matched the retention time of gallic acid as shown in Figure 1. In addition, the chemical structure of the isolated compound was identified by spectroscopic methods and compared with the literature. It was identified as a known compound, gallic acid (Figure 2). Fraction E4.4.5 was obtained as a yellow-green powder in yield $(2.05 \mathrm{~g}, 0.21 \%)$. It was crystallized in chloroform. ${ }^{1} \mathrm{H}$ NMR (DMSO-d6): $\delta 6.90$ (2H, s, H-3 and H-7) $\delta 8.80$ $(1 \mathrm{H}, \mathrm{s}, 5-\mathrm{OH})$ and $\delta 9.22(2 \mathrm{H}, \mathrm{s}, 4-\mathrm{OH}$ and $6-\mathrm{OH}) ;{ }^{13} \mathrm{C}$ NMR (DMSO-d6): $\delta 167.9$ (C-1), $\delta 145.8$ (C-4 and C-6),

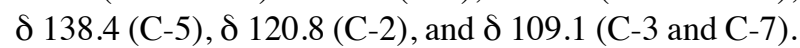

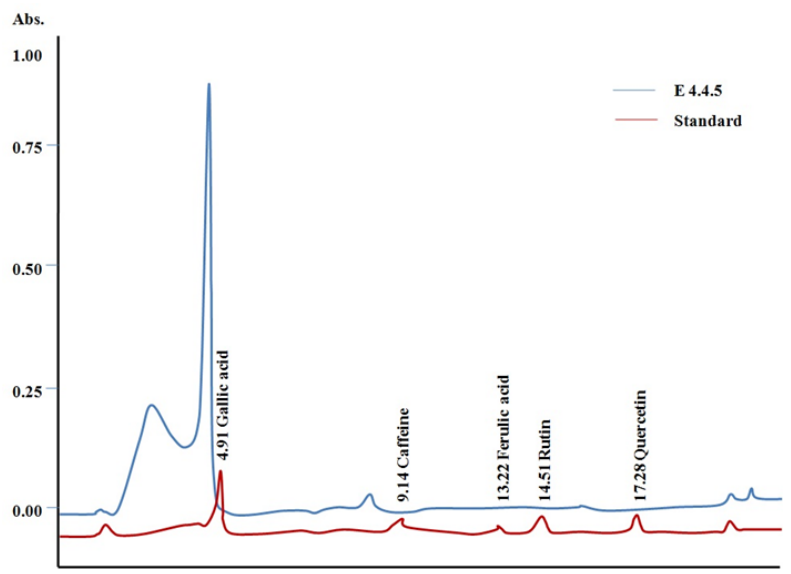

Figure 1. HPLC Chromatogram of C. Mimosoides Lamk Extract Fraction E4.4.5 Compared with the Standard Phytochemical Compounds Gallic Acid, Catechin, Caffeine, Ferulic Acid, Rutin, and Quercetin
Growth inhibition of CCA cells by gallic acid from $C$. mimosoides Lamk

The effects of nGA compared to cGA on 2 cell lines were tested. The results showed that the $\mathrm{IC}_{50}$ value of nGA was similar to cGA in all cells tested (Table 1). The $\mathrm{IC}_{50}$ values of $\mathrm{nGA}$ when treating M213 and M214 were 120 and $124 \mu \mathrm{M}$, respectively. The $\mathrm{IC}_{50}$ values of cGA when treating M213 and M214 were 119 and $147 \mu \mathrm{M}$, respectively. Treatment of all cells with $\mathrm{nGA}$ and cGA resulted in similar marked suppression of cell proliferation in a dose-dependent manner. The morphological alterations of M213 and M214 cells treated with cGA were observed with a fluorescence microscope. In the fixed DAPI-stained cells, smaller and more brightly stained nuclei were observed, indicating cell death by apoptosis (Figure 3).

Antibacterial activities of gallic acid from C. mimosoides Lamk against foodborne bacteria

The MIC of nGA for the bacterial species Salmonella spp. (serogroup B) and Plesiomonas shigelloides was

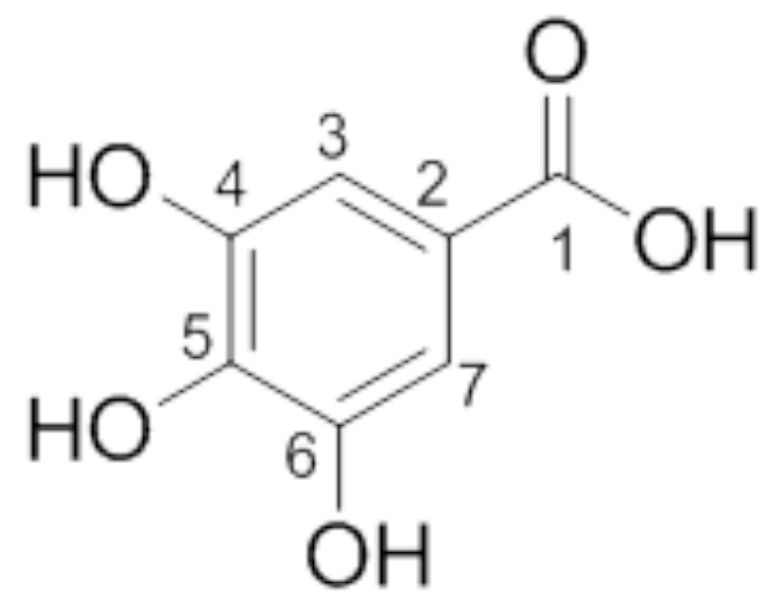

Figure 2. Chemical Structure of Gallic Acid

Table 1. The $\mathrm{IC}_{50}$ Values of Gallic Acid from $\boldsymbol{C}$. Mimosoides Lamk and Commercial Gallic acid on CCA Cell Lines

\begin{tabular}{lcc}
\hline Cell lines & \multicolumn{2}{c}{$\mathrm{IC}_{50}$} \\
\cline { 2 - 3 } & $\begin{array}{r}\mathrm{nGA} \\
(\mu \mathrm{M})\end{array}$ & $\begin{array}{c}\mathrm{cGA} \\
(\mu \mathrm{M})\end{array}$ \\
\hline M213 & 120 & 119 \\
$\quad$ Well-differentiated adenocarcinoma & & \\
$\begin{array}{l}\text { M214 } \\
\quad \text { Moderately differentiated adenocarcinoma }\end{array}$ & 124 & 147 \\
\hline
\end{tabular}

Table 2. The MIC Values of Gallic Acid from C. Mimosoides Lamk and Commercial Gallic Acid for Salmonella spp. (Serogroup B) and Plesiomonas Shigelloides

\begin{tabular}{lcc}
\hline Bacteria & nGA $(\mathrm{mM})$ & $\mathrm{cGA}(\mathrm{mM})$ \\
\hline Salmonella spp. & 120 & 120 \\
Plesiomonas shigelloides & 120 & 110 \\
\hline
\end{tabular}




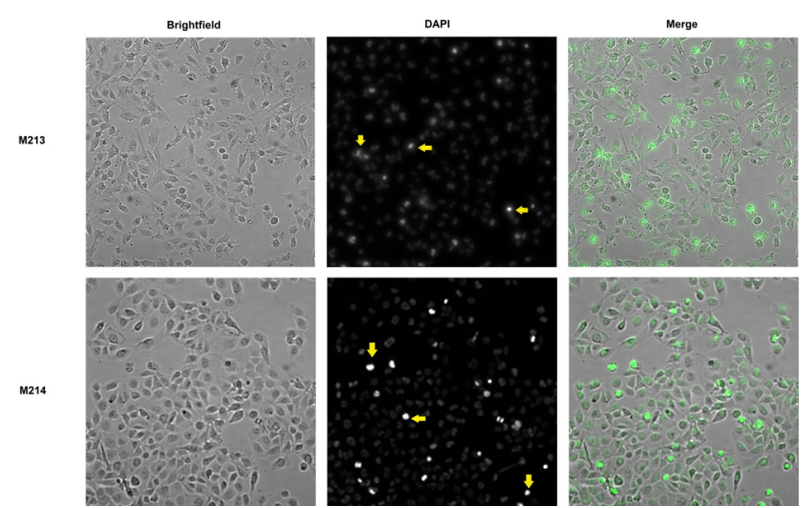

Figure 3. The Morphological Alterations of M213 and M214 Cells Induced by IC $_{50}$ Values of cGA for $24 \mathrm{hr}$ were Observed by Staining with DAPI and Analyzing Under a Fluorescence Microscope. The smaller and more brightly stained nuclei are indicated by the arrows

(a)
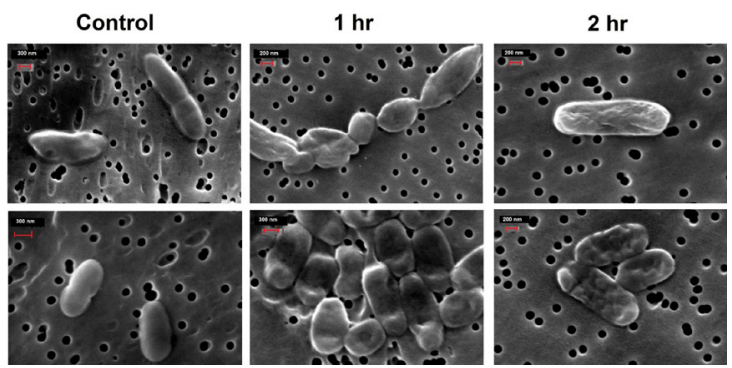

Figure 4. The scanning Electron Microscopic Showed Bacterial Membrane Disruption after Treatment with the MIC of cGA for (A) Salmonella spp. (serogroup B) and (B) Plesiomonas Shigelloides. Negative Controls were Treated with $0.9 \%$ Sodium Chloride; Bar $=1$ Micrometer

$120 \mathrm{mM}$. Similarly, cGA has MIC values of 120 and 110 $\mathrm{mM}$ for Salmonella spp. (serogroup B) and Plesiomonas shigelloides, respectively (Table 2). SEM analysis showed that the bacterial membrane was wrinkled following treatment with $120 \mathrm{mM}$ cGA to Salmonella spp. (serogroup B) (Figure 4A) and $110 \mathrm{mM} \mathrm{cGA}$ to Plesiomonas shigelloides (Figure 4B) for 1 and $2 \mathrm{hr}$, respectively.

\section{Discussion}

Fraction E4.4.5 was extracted using EtOAc, and the resulting powder (yield $2.05 \mathrm{~g}, 0.21 \%$ ) was identified as gallic acid. The bioactive substances in $C$. mimosoides Lamk are polar compounds rather than non-polar compounds, as has been described in previous studies (Kim2007; Chanwitheesuk et al., 2005; Chanwitheesuk et al., 2007; Yodsaoue et al., 2010; Palasap et al., 2014).

M213 and M214 cells were treated with cGA to assess its anticancer activity. The fixed cells were DAPI stained, and smaller, brighter nuclei were observed with a fluorescence microscope, indicating that the cells had undergone apoptosis (Figure 3). This result is similar to those of several studies reporting that gallic acid is an anticancer agent that significantly inhibits cell proliferation and induces apoptosis. Faried et al. (2007) reported that gallic acid induced apoptosis in esophageal cancer cells (TE-2) by upregulating the pro-apoptotic protein Bax and downregulating the anti-apoptotic proteins Bcl-2 and Xiap and the Akt/mTOR survival pathway. You et al. (2010) found similar results using gallic acid and HeLa cervical cancer cells. Chandramohan et al.,(2012) reported that gallic acid induced apoptosis in a chronic myeloid leukemia cell line (K562) through the death receptor and mitochondrial-mediated pathways via inhibition of BCR/ ABL kinase, NF- $\varkappa \mathrm{B}$ and COX-2. Daduang et al. (2015) found that caspases $3 / 7,8$, and 9 were significantly more active in HeLa cells treated with gallic acid, indicating the induction of apoptosis via intrinsic and extrinsic pathways. However, $\mathrm{SiHa}$ and $\mathrm{C} 33 \mathrm{~A}$ cells only showed increased caspase 8 levels, revealing that gallic acid induced apoptosis via the intrinsic pathway in these cell lines. Moreover, Rattanata et al. (2015) used Fourier transform infrared spectroscopy (FTIR) analysis and found a lipid signal $(2948,2835,2915$, and $2848 \mathrm{~cm}-1)$ that was a strong marker of apoptosis in cholangiocarcinoma cells (M213) treated with gallic acid.

The antibacterial activity of nGA against 2 gramnegative pathogenic bacterial strains was compared to treatment with cGA. The MIC of gallic acid from these two different sources was the same, suggesting that nGA affected the bacterial cell membrane in the same manner as cGA. The primary action of phenolic acids on the cell membrane has been supported by several published works. Ramos-Nino et al. (1996) found that the antilisterial activity of phenolic acids was dependent on the lipophilicity and degree of ionization of the molecules. Other groups also found the phenolic acid activity against Listeria monocytogenes to be dependent on $\mathrm{pH}$, which is consistent with the passive diffusion of phenolic acids through the cell membrane (Kouassi and Shelef, 1998; Wen et al., 2003). Moreno et al. (2006) reported that phenolic compounds can penetrate a cell due to changes in its membrane permeability. Altogether, the results indicate that most of the phenolic acids (particularly those from $C$. mimosoides Lamk) alter bacterial size and shape, and this was observed in both gram-negative and gram-positive bacteria (Daduang et al, 2011).

In conclusion, this study demonstrates the bioactivity of extracts from C. mimosoides Lamk. We successfully isolated an active substance, gallic acid, using an ethyl acetate extraction. The nGA exhibited both anticancer activity and antimicrobial activities with similar $\mathrm{IC}_{50}$ and MIC values to cGA. Our results suggest that gallic acid may be a potential anticancer and antibacterial agent; however, in depth in vivo studies are needed to elucidate the exact mechanism.

\section{Acknowledgements}

This work was supported by the Higher Education Research Promotion and National Research University Project of Thailand, Office of the Higher Education Commission through the Center of Excellence in Specific Health Problems in the Greater Mekong Subregion cluster (SHeP-GMS), Khon Kaen University, 
Thailand (Ph.D.54208 to Rattanata N and NRU542014 to Daduang J). The authors thank the Liver Fluke and Cholangiocarcinoma Research Center for providing the CCA cell lines.

\section{References}

Abatcha MG, Zakaria Z, Kaur DG, Thong KL (2014). Review article: a trends of Salmonella and antibiotic resistance. $A d v$ Life Sci Tech, 17, 1-21.

Bauer AW, Kirby WM, Sherris JC, Turck M (1966). Antibiotic susceptibility testing by a standardized single disk method. Am J Clin Pathol, 45, 493-6.

Chandramohan RT, Bharat RD, Aparna A, et al (2012). Antileukemic effects of gallic acid on human leukemia K562 cells: downregulation of COX-2, inhibition of BCR/ABL kinase and NF- $x$ B inactivation. ToxicolIn Vitro, 26, 396-405.

Chanwitheesuk A, Teerawutgulrag A, Kilburn JD, et al (2007). Antimicrobial gallic acid from Caesalpinia Mimosoides Lamk. Food Chem, 100, 1044-8.

Chanwitheesuk A, Teerawutgulrag A, Rakariyatham N (2005). Screening of antioxidant activity and antioxidant compounds of some edible plants of Thailand. Food Chem, 92, 491-7.

Collignon P (2009). Resistant Escherichia coli-we are what we eat. Clin Infect Dis, 49, 202-4.

Daduang J, Palasap A, Daduang S, Boonsiri P, Suwannalert $P$, Limpaiboon T (2011). High phenolics and antioxidants of some tropical vegetables related to antibacterial and anticancer activities. Afr J Pharm Pharacol, 5, 608-15.

Faried A, Kurnia D, Faried LS, et al (2007). Anticancer effects of gallic acid isolated from Indonesian herbal medicine, Phaleriamacrocarpa (Scheff.) Boerl, on human cancer cell lines. Int J Oncol, 30, 605-13.

Kande JA, Hayashi Y (1998). Potency of extract contents from selected tropical chewing sticks against Staphylococcus aureus and Staphylococcus auricularis. World J Microbiol, 14, 235-8.

Khan SA, Davidson BR, Goldin R, et al (2002). Guidelines for the diagnosis and treatment of cholangiocarcinoma: consensus document. Gut, 51, 1-9.

Kim YJ (2007). Antimelanogenic and antioxidant properties of gallic acid. Biol Pharm Bull, 30, 1052-5.

Kouassi Y, ShelefLA(1998). Inhibition of Listeria monocytogenes by cinnamic acid: possible interaction of the acid with cysteinyl residues. J Food Safety, 18, 231-42.

Moreno S, Scheyer T, Romano CS, Vojnov AA (2006). Antioxidant and antimicrobial activities of rosemary extracts linked to their polyphenol composition. Free Radic Res, 40, 223-31.

Palasap A, Limpaiboon T, Boonsiri P, et al (2014). The cytotoxic effect of phytophenolics form Caesalpinia Mimosoides Lamk on cervical carcinoma cell lines through apoptotic pathway. Asian Pac J Cancer Prev, 15, 449-54.

Ramos-Nino ME, Clifford MN, Adams MR (1996). Quantitative structure activity relationship for the effect of benzoic acids, cinnamic acids and benzaldehydes on Listeria monocytogenes. J Appl Bacteriol, 80, 303-10.

Rattanata N, Daduang S, Wongwattanakul M, et al (2015). Gold nanoparticles enhance the anticancer activities of gallic acid against cholangiocarcinoma cell lines. Asian Pac J Cancer Prev, 16, 7143-7.

Tangsaengvit N, Kitphati W, Tadtong S, Bunyapraphatsara N, Nukoolkarn V (2013). Neurite outgrowth and neuroprotective effects of quercetin from Caesalpinia Mimosoides Lamk on cultured P19-derived neurons. Evid Based Complement Alternat Med, 838051.
Thongprasert S (2005). The role of chemotherapy in cholangiocarcinoma. Ann Oncol, 16, 93-6.

Uawonggul N, Thammasirirak S, Chaveerach A, et al (2007). Purification and characterization of heteroscorpine-1 (HS-1) toxin from Heterometruslaoticus scorpion venom.Toxicon, 49, 19-29.

Wen AM, Delaquis P, Stanich K, Toivonen P (2003). Antilisterial activity of selected phenolic acids. Food Microbiol, 20, 305-11.

World health organization. The top ten causes of death. (2012).

Yodsaoue O, Karalai C, Ponglimanont C, et al (2010). Potential anti-inflammatory diterpenoids from the roots of Caesalpinia Mimosoides Lamk. Phytochemistry, 71, 1756-64.

You BR, Moon HJ, Han YH, Park WH (2010). Gallic acid inhibits the growth of HeLa cervical cancer cells via apoptosis and/or necrosis. Food ChemToxicol, 48, 1334-40. 